\title{
Age of menarche in Indian female basketball and volleyball players at different competitive levels
}

\author{
R. Mokha and L.S. Sidhu
}

Department of Human Biology, Punjabi University, Patiala, India

\begin{abstract}
Data for the age of menarche have been collected on 98 female volleyball players and 75 basketball players. The players belonged to four different levels of competition: international, national, intervarsity and district. Menarche is significantly delayed in players as compared with the controls. There is a continuous trend of increase in the age of menarche with the increasing levels of competition; menarche is more delayed in players playing at a higher level than those at the lower levels of competition.
\end{abstract}

Keywords: Menarche, physical activity, levels of participation, basketball, volleyball

\section{Introduction}

Strenuous physical training for female athletes in topclass competition has raised questions with regard to its effect on their physiological functions. Important considerations centre on the influence of the varying degrees of intensity of training on the age of menarche. Strenuous physical activity is known to delay menarche in sportswomen ${ }^{1-4}$. Sidhu and $\mathrm{Grewal}^{4}$ further reported that menarche is significantly delayed in those players who started participating in games before the onset of puberty as compared with those who started playing after the onset of puberty ${ }^{4}$.

The present study has been undertaken to investigate whether the level of participation has any effect on the age of menarche.

\section{Materials and methods}

Data on the age of menarche have been collected on 75 female basketball players and 98 female volleyball players. Eighty one subjects formed the control group. Most players and controls belonged to the Punjab state. The players were classified according to their level of participation as either international, national, intervarsity or district level. International level is the highest level of participation and the district level is the lowest level of participation in the present series. International players are those who represented India in an international competition and such players are available only in volleyball in this study.

Address for correspondence: Dr (Mrs) R. Mokha, Department of Human Biology, Punjabi University, Patiala-147002, India

(C) 1989 Butterworth \& Co (Publishers) Ltd 0306-3674/89/040237-02 \$03.00
Table 1. Mean age of menarche in controls and players of basketball and volleyball at different levels of competition

\begin{tabular}{lcccc}
\hline & & & & $\begin{array}{c}\text { t test } \\
\text { with control }\end{array}$ \\
& $N$ & Mean & $S D$ & - \\
Control & 81 & 14.39 & 1.39 & \\
& & Basketball & & $3.58^{*}$ \\
National & 24 & 15.53 & 1.29 & $2.43^{*}$ \\
Intervarsity & 19 & 15.23 & 1.20 & $2.57^{*}$ \\
District & 32 & 15.18 & 1.66 & $4.07^{*}$ \\
All levels combined & 75 & 15.31 & 1.43 & \\
& & Volleyball & & 1.05 \\
International & 14 & 14.82 & 1.54 & $3.22^{*}$ \\
National & 47 & 15.26 & 1.60 & $2.07^{*}$ \\
Intervarsity & 15 & 15.18 & 1.11 & 1.66 \\
District & 22 & 14.96 & 1.58 & $3.34^{*}$ \\
All levels combined & 98 & 15.12 & 1.51 & \\
\hline
\end{tabular}

*Statistically significant at 5 per cent level

The age of menarche was obtained by the recall method. According to Damon et al. ${ }^{5}$ recalled age at menarche is accurate enough for anthropological and epidemiologic purposes involving group comparisons ${ }^{5}$. However, additional care was taken in the study and only those girls were included in the study who could easily recall their exact age of menarche.

\section{Results and discussion}

Table 1 gives the mean age of menarche in the players and controls. Menarche is significantly delayed in the players of basketball and volleyball as compared with the controls. However, the delay is slightly more in the basketball players than the volleyball players.

The players in each game were divided into two groups; group A includes those players who started participating in games before the onset of puberty, and group $B$ includes those who started participating in games after the onset of puberty. It can be observed from Table 2 that menarche is significantly delayed in the players of group A as compared with the players of group B. When the players of groups A and B in both the games are compared with the control group, it is interesting to observe that a significant delay in the age of menarche is observed only in the players of group A, whereas the players of group B do not differ statistically from the controls (Table 3 ). 
Table 2. Mean age of menarche in basketball and volleyball players who started playing either before the onset of menarche (Group A) or after menarche (Group B)

\begin{tabular}{|c|c|c|c|c|c|}
\hline \multirow[b]{2}{*}{ Game } & \multicolumn{2}{|r|}{ Group A } & \multicolumn{2}{|r|}{ Group B } & \multirow{2}{*}{$\begin{array}{c}\text { Ttest } \\
\text { betweer } \\
A \& B\end{array}$} \\
\hline & $N$ & Mean $\pm S D$ & $N$ & Mean $\pm S D$ & \\
\hline Basketball & 30 & $\begin{array}{ll}15.90 & 1.29\end{array}$ & 28 & $14.67 \quad 1.34$ & $3.54^{*}$ \\
\hline Volleyball & 55 & $\begin{array}{ll}15.66 & 1.53\end{array}$ & 22 & $\begin{array}{ll}14.10 & 1.27\end{array}$ & $4.23^{*}$ \\
\hline
\end{tabular}

*Statistically significant at 5 per cent level

It suggests that the strenuous physical activity in which the players were involved before puberty may have delayed menarche. Similar results were reported by Orosz et al. ${ }^{6}$, Sidhu and Grewal ${ }^{4}$, Frisch et al. ${ }^{7}$ and Malina $^{8}$. It also suggests that intensive training may delay the menarche.

It was interesting to sub-divide the data into $A$ and $B$ groups at each level of participation in both the sporting categories (Table 4). However, the number of subjects in some low categories has rendered the statistical tests inapplicable. Table 4 shows that menarche is more delayed in the players of group A than the group B players at each level of participation in both the games. The maximum delay is observed in the national players of basketball, followed by the national players of volleyball. In other words, the maximum delay in the age of menarche is observed in the players of national level i.e. the higher level of participation.

It is important to mention here that the players of the group A of international level in volleyball show a minimum delay in the age of menarche, even though they belong to the highest level of competition. The reason attributed to this could be that out of the 14 players of international level in volleyball, eight were from Bengal, one from Tamil Naidu, one from Rajasthan, one from Kerala, two from Delhi and one from Punjab. Debnath et al. studied the menstrual patterns of female players from nine different states and reported that menarche starts earlier in Bengal and Tripura states, followed by Maharashtra, Goa and Bihar and that it appears later in Rajasthan, Karnataka and Assam ${ }^{9}$. Since in the international volleyball team, the majority of the players are from Bengal state, this could explain the early menarche in these players.

It is thus concluded that menarche is more delayed in players at higher levels of competition. Malina et al. reported an association between delayed menarche and more advanced competitive levels in several sports except swimming ${ }^{2}$. He also suggested that lateness in maturity may be related to success in some sports. Espenschade also reported that the girls classified as the better performers were more commonly later maturing girls ${ }^{10}$.

\section{References}

1 Malina, R.M., Harper, A.B., Avent, H.H. and Campbell, D.E. Age of menarche in athletes and nonathletes Med Sci Sport 1973, 5, 11-13
Table 3. T test applied to age of menarche, between the controls and groups $A$ and $B$ of basketball and volleyball

\begin{tabular}{ccc}
\hline Game & & $\begin{array}{c}\text { t test with } \\
\text { control }\end{array}$ \\
\hline Basketball & Group A & $5.13^{*}$ \\
& Group B & 0.93 \\
Volleyball & Group A & $4.98^{*}$ \\
& Group B & 0.89 \\
\hline
\end{tabular}

*Statistically significant at 5 per cent level

Table 4. Age of menarche in groups A and B of basketball and volleyball players at different competitive levels

\begin{tabular}{|c|c|c|c|c|c|c|}
\hline & \multicolumn{3}{|c|}{$\begin{array}{l}\text { Group A } \\
\text { (Those players who } \\
\text { started playing before } \\
\text { the onset of menarche) }\end{array}$} & \multicolumn{3}{|c|}{$\begin{array}{c}\text { Group B } \\
\text { (Those players who } \\
\text { started playing after } \\
\text { the onset of menarche) }\end{array}$} \\
\hline & $N$ & Mean & $S D$ & $N$ & Mean & $S D$ \\
\hline \multicolumn{7}{|c|}{ Basketball } \\
\hline National & 8 & 16.33 & 1.10 & 13 & 14.93 & 1.25 \\
\hline Intervarsity & 7 & 15.37 & 1.60 & 6 & 14.53 & 0.90 \\
\hline District & 16 & 15.73 & 1.39 & 9 & 14.52 & 1.63 \\
\hline \multicolumn{7}{|c|}{ Volleyball } \\
\hline International & 12 & 14.96 & 1.57 & 2 & 14.00 & - \\
\hline National & 24 & 16.17 & 1.33 & 15 & 13.91 & 1.35 \\
\hline Intervarsity & 6 & 15.93 & 1.19 & 2 & 14.50 & - \\
\hline District & 14 & 15.23 & 1.65 & 4 & 14.23 & 1.35 \\
\hline
\end{tabular}

*Statistically significant at 5 per cent level

2 Malina, R.M., Spirduso, W.W., Tate, C. and Baylor, A.M. Age at menarche and selected menstrual characteristics in athletes at different competitive levels and in different sports Med Sci Sports 1978, 10, 218-222

3 Malina, R.M., Bouchard, C., Shoup, R.F., Demirjian, A. and Larieviere, G. Age at menarche, family size and birth order in athletes at the Montreal Olympic Games 1976 Med Sci Sports 1979, 11, 354-358

4 Sidhu, L.S. and Grewal, R. Age of menarche in various categories of Indian sportswomen Br J Sports Med 1980, 14, 199-203

5 Damon, A., Damon, S.T., Reed, R.B. and Valadian, I. Age at menarche of mothers and daughters with a note on accuracy of recall Hum Biol 1969, 41, 161-175

6 Orosz, K., Ciora, Z. and Murmurache, A. Endokrinologiai es nogyogyaszati megfigyelesek elsportolo nokon. In A Magyar Sportorvos Tarsasag Tudamanyos Kongresszusa ed by O. Arato and V. Grubich, Budapest TTT 1972, 82-85

7 Frisch, R.E., Gotz-Wilbergen, A.V., McArthur, J.W., Albright, T., Witschi, J., Bullen, B., Birnholz, J., Reed, R.B. and Hermann, $H$. Delayed menarche and amenorrhea of college athletes in relation to age of onset of training JAMA 1981, 246, 1559-1563

8 Malina, R.M. Menarche in athletes: A synthesis and hypothesis Ann Hum Biol 1983, 10, 1-24

9 Debnath, P.K., Chakraborty, B. and De, A.K. Status of menstruation among the IV women festival participants (1978-79) and to study the efficiency during menstruation Proc. of the IX Annual Conference of Indian Association of Sports Medicine 5th and 6th April 1980, Calcutta

10 Espenschade, A. Motor performance in adolescence Monogr Soc Res Child Dev 1940, 5, 1-126 